\title{
Learning Difficulties and Opportunities for Student and Academics of Malaysian Institutions of Higher Learning (MIHL) in the Covid-19 Pandemic Outbreak
}

\author{
Juhary Ali $^{1}$, Sheila Cheng ${ }^{2}$, Jeffrey Chiang ${ }^{3}$ \\ \{juhary.ali@aeu.edu.my ${ }^{1}$, sheila.cheng@aeu.edu.my ${ }^{2}$, jeffreychiang@ segi.edu.my ${ }^{3}$ \} \\ Asia e University Malaysia, Kuala Lumpur ${ }^{1}$, Asia e University Malaysia, Kuala Lumpur ${ }^{2}$, Asia e \\ University Malaysia, Kuala Lumpur ${ }^{3}$
}

\begin{abstract}
In this Covid-19 pandemic crisis education for students at all levels in Malaysia were instructed to shut down. There were many issues arising from this development, which caused difficulties in maintaining the standards of teaching and learning by both lecturers or teachers and the students and their parents. Difficulties and problems faced by students include poor or lack of internet connection facility, unreliable computer and mobile devices, challenges in learning without face to face contacts, unhealthy hours spent in front of computer or mobile screens, lack of concentration and built up of stresses and uncertainties in their academic performance. These are all common issues that all students of higher learning had faced during this challenging time. Meanwhile, there are opportunities for students and lecturers, in the form of having flexibility of learning at their own pace in their home environment, not having to travel on the road allows more time to plan or work on other areas of interest, ability to expand on knowledge of online connection and even going into online business transactions, able to connect regularly with friends and relatives in faraway places - in other words, this pandemic crisis seems to be preparing us all for the future where technologies such as 5G connectivity and Industrial Revolution 4.0 will prevail in the world economy and daily activities.
\end{abstract}

Keywords: Covid-19, learning difficulties and opportunities, institutions of higher learning.

\section{Introduction}

The Covid-19 viral crisis was an unexpected watershed event, as it reached the critical stage in Malaysia in late February to early March 2020. The nation went into lockdown on 18 March 2020 after experiencing a sudden spike in Covid-19 infection cases in a mass Muslim religious gathering of tens of thousands in Klang Valley close to Kuala Lumpur [1][2]. The sudden rise in hundreds of infection cases was deemed a national security threat. In the interest of public health and safety, the National Security Council (NSC) was activated via the National Security Council Act 2016 (Act 776)to control the pandemic on a national scale [3]. 
COVID-19 was deemed a national security threat, the National Security Council (NSC) was activated via the National Security Council Act 2016 (Act 776) to command and mobilise all government and non-governmental machineries.

Everyone has to remain indoors for weeks on end, and all public amenities, commercial activities and entertainment outlets are forced to suspend or close their operations, with the exception of essential services such as banking, transportation, food delivery and medical. [4] The progress of students in their current study in universities were the first priority of all educationists. All universities at both private and public sectors allocated equipment and human resources to ensure that their teaching and learning facility are able to handle the online teaching and learning environment to be conducive for both students and lecturers. [4] Students and lecturers alike have to undergo self-training or arranged training in order to know and be well versed in the use of online learning and teaching platforms, such as Zoom, Webex, Google Meet, Microsoft Teams and many more of such commercially available online tools for mass internet connections [5].

\section{Methods}

This paper outlines the issues and challenges faced by students and lecturers during the Covid-19 pandemic crisis in the universities' learning environment. Issues faced by people in the school levels, be it at secondary, primary or even at kindergarten are not addressed here.

The problems and opportunities as highlighted in this paper are those faced in the Malaysian context, some of which are unique, while there are other issues which are commonly found regionally or globally.

\section{Result and Discussion}

\subsection{Difficulties faced by students}

From the beginning of national lockdown from 18 March 2020, both academic staff and students were refused entry into their university premises, but due to the two-day notice given, academic staff were given prior notification to prepare themselves to conduct their classes online via suitable internet platform. The same goes with the students, and those who were not in campus or even traveling abroad may have been stranded without adequate facility and conveniences to $\log$ into the internet for their online classes.

The main crux of the difficulty faced by students is the inability to maintain the same level of quality in learning that they have been receiving via face-to-face classroom teaching. This is hampered mainly due to students having stranded in their hometowns isolated from urbanized areas, resulting in unreliable internet connection to facilitate online learning [5] [6] [7].

Besides this, those students who were able to access online platforms complained of tedious and boring learning environment, having to sit and remain stagnant in front of the PC monitor or worse their mobile devices for long hours. This is compounded also by the lack of face-to-face interaction with their lecturers and classmates, which made the atmosphere to be non-conducive in effective learning. 
In the long run, students having to go from one online class to another, repeatedly will face boredom and having less concentration and motivation to absorb and appreciate the knowledge being imparted through the online medium. There have been cases, where students faced high level of stress especially during the examinations and online assessments, when they felt isolated and alone facing the brunt of examination questions with minimum guidance from the lecturers.

Other than the above difficulties commonly faced by students in this trying time, the lack of mobility and opportunity to have direct access for face-to-face consultation in campus, may give rise to students with low self-esteem and lack of confidence in the face of unknown challenges ahead.

\subsection{Difficulties faced by lecturers}

There are those fortunate lecturers who are well-trained in the use of distance learning mode, either in Open Learning or MOOC (massive open online course) - hence when this Covid-19 crisis struck, they are well-placed to undertake the tasks of handling online teaching, and able to provide quality and comprehensive teaching using online platform to the students. On the other hand, those lecturers who are engaged in the traditional methods of face-to-face or big lecture hall teaching would face many challenges in switching over to the faceless teaching mode, and this will be reflected in poor teaching evaluation by students and their superiors at the faculties.

The pressure and stress involved in getting the right and quality teaching across to students in a distance learning mode are immense for some of the lecturers who are not technology savvy, especially those in non-technology fields. Some do faced poor internet connection at home, and they may have to fork out their own funds to upgrade their home internet services, and even their computer equipment and gadgets to keep up with the pace and wide scope of internet tools available in the market [5] [6] [7].

More energy and time are spent and consumed by lecturers, to prepare online teaching materials and then to use proper equipment to deliver the lectures. Proper methods of online assessment and examinations have to be learnt, in order to ensure smooth running of examination with no hiccups in students' complaints of unfairness of questions set and given duration for download and upload of submissions on time via the computerized system of the university network.

Some lecturers do complained that the work involved in online teaching are more extensive and wide-ranging than normal face-to-face classroom teaching. And their predicament is made worse by the University Management which instituted salary deduction or pay cut across the board, due to financial constraint in the pandemic crisis. This has resulted in high level of stress and uncertainties among the academic staff.

Besides the teaching workload, the academic staff are expected to continue their research work as part of their key performance index. This is made much more difficult during this pandemic crisis with lockdown, rendering research work to be at a standstill since no physical contacts are allowed with industry people, and research students not able to use university facilities for their research supervised by these academic staff.

These are all common issues that all academic staff of higher learning had faced during this challenging time.

\subsection{Opportunities for students}


The fact that students are learning from their homes, means that they can learn at their own pace with flexibility in time management within their home environment. By not having the need to be on the road traveling to and fro from home to campus, the students would have time and luxury to plan and work on other areas of their interest - be it in academic or nonacademic.

Some students even ventured into online business on their own using their learnt skills and knowledge of using computerized technology to connect with the outside world in real time. And by using the internet widely, the students can have direct access to information readily to complete their work assignments quickly and comprehensively - all at the touch of the keyboard with their fingers.

In short, the learning curve has become much steeper for the students and their young minds can keep pace easily with the fast paced development in 5G technology and the coming industrial revolution 4.0. With the right mind and right attitude, the future is limitless for the students, who can capitalize on the use of online platform, not just for teaching and learning but for much more opportunities in their future career development and lifelong learning.

\subsection{Opportunities for lecturers}

The same opportunities that lie ahead for students can also be available for the academic staff, to expand their knowledge and involvement into the industry in a way not done before. The connectivity they can have is limitless, in terms of seeking advantage in latest knowledge and information pertaining to research and teaching as well [5].

The lecturers would have more flexibility in teaching at their own pace in their home environment, not having to travel on the road allows more time to plan or work on other areas of interest, ability to expand on knowledge of online connection and even going into online business transactions, able to connect regularly with friends and relatives in faraway places in other words, this pandemic crisis seems to be preparing the lecturer themselves all for the future where technologies such as $5 \mathrm{G}$ connectivity and Industrial Revolution 4.0 will prevail in the world economy and daily activities.

\subsection{What is the future for us all in Post Covid-19?}

In the future scenario, post Covid-19, we will expect wide usage of technology in the learning and teaching professions, right across the board from early childhood right up to postgraduate studies at university level. Course content in the higher institute of learning will become much more diverse and customized to the student's ability and interest. The opportunity to learn will be rethought and will focus on career readiness (Hong and Lissitz, 2020) [8]. The expectation will be of the Government to institute the right regulations and incentives to allow the use of correct online platforms to deliver classroom teaching in a distance mode.

Swart \& MacLeod [9] (2020) conducted a study on analytics classes taught face-to-face $(\mathrm{F} 2 \mathrm{~F})$ at the undergraduate and graduate levels which were emulated in corresponding online classes. They found that the flipped learning is transferrable to online analytics courses and yields student satisfaction at par with equivalent F2F flipped courses.

Another study done by Williams, Martinasek, Carone, and Sanders [10] (2020) on high school students' perceptions of traditional and online health and physical education courses. The results indicated that students' positive perceptions on an online class may equal or surpass those in a traditional F2F format. In addition, the study also showed that youth are 
increasing exhibiting enhanced capacity for online-based coursework. Physical education classes have traditionally been F2F, but warrant further consideration as an online platform.

The use of technology will happen not just in the education industry, but across every economy sector in the country, be it in the manufacturing, construction, banking and finances, agriculture and all services providers.

The future ahead is already well-defined for us, and the challenge is for us, the academics to grasp and to take advantage of the changes ahead - so that we can equip ourselves better and to adapt well to the changing environment ahead.

\section{Conclusion}

It seems that this Covid-19 pandemic crisis is preparing us well in advance for the future where technologies such as $5 \mathrm{G}$ connectivity and Industrial Revolution 4.0 will prevail in the world economy and our daily activities. The teaching professions such as it is in the universities have to change and adapt themselves in order to stay relevant for the future.

The use of online mode of teaching and learning is here to stay and will be widely used and expand both in the public and private sectors alike. Both the academics and university administrators will have to face these challenges ahead, with students who are coming of age into the $5 \mathrm{G}$ generation.

\section{References}

[1] Elengoe, A.: COVID-19 Outbreak in Malaysia. Osong Public Health and Research Perspectives 2020; 11(3): 93-100(May 11, 2020). DOI: https://doi.org/10.24171/j.phrp.2020.11.3.08 Retrieved from https://ophrp.org/journal/view.php?number=559

[2] Reuters : How Sri Petalingtabligh became Southeast Asia's Covid-19 hotspot. New Straits Times (March 17, 2020). Retrieved from https://www.nst.com.my/news/nation/2020/03/575560/how-sripetaling-tabligh-became-southeast-asias-covid-19-hotspot

[3] Institute for Health Systems Research: Universal Health Coverage and COVID-19 Preparedness \& Response, Malaysia (2020)

[4] New Straits Times:14-day Movement Control Order begins nationwide on Wednesday(March 16, 2020). Retrieved from https://www.nst.com.my/news/nation/2020/03/575180/14-day-movementcontrol-order-begins-nationwide-wednesday

[5] Mustapha R.: Challenges of Online Teaching. The New Strait Times (June 1, 2020). Retrieved from https://www.nst.com.my/opinion/columnists/2020/06/596794/challenges-online-teaching

[6] Fernandes, S. M.: Teachers face challenges as online classes gather steam. Times of India (TOI) (June 5, 2020). Retrieved from https://timesofindia.indiatimes.com/blogs/edutrendsindia/challenges-of-quality-in-online-learning/

[7] Friedman, J.:Tackle Challenges of Online Classes Due to COVID-19(May 4, 2020). Retrieved from https://www.usnews.com/education/best-colleges/articles/how-to-overcome-challenges-of-on lineclasses-due-to-coronavirus

[8] Hong, J. and Lissitz, R. W.: What Hath the Coronavirus Brought to Assessment? Unprecedented Challenges in Educational Assessment in 2020 and Years to Come. Educational Measurement: Issues and Practice, Vol. 0, No. 0, pp. 1-4(2020)

[9] Swart, W. W. and MacLeod, K. R.: Flipping online analytics classes: achieving parity with their face-to-face counterparts. Decision Sciences Journal of Innovative Education, Vol 18, Issue 1 (2020)

[10] Williams, L., Martinasek, M., Carone, K., and Sanders, S.: High School Students' Perceptions of 
Traditional and Online Health and Physical Education Courses. Journal of School Health, American School Health Association (2020). https://doi.org/10.1111/josh.12865. Retrieved from: https://online library.wiley.com/doi/10.1111/josh.12865 